\title{
READINESS OF THE SWAZILAND SUGAR INDUSTRY TOWARDS THE USE OF INFORMATION AND COMMUNICATION TECHNOLOGY: PERCEPTIONS OF SMALLHOLDER SUGARCANE FARMERS AND EXTENSION OFFICERS
}

\author{
Dlamini, M. M. ${ }^{1}$ and Worth, S. $^{2}$ \\ Correspondence author: M. M. Dlamini. Email: $\underline{\text { mzmdlamini@gmail.com }}$
}

\begin{abstract}
The study investigated smallholder sugarcane farmers and extension officers' perceptions of readiness towards the use of Information and Communication Technology (ICT), especially cell phones, as a source of technology for accessing information within the Swaziland sugar industry. The study was a census involving all active smallholder sugarcane farmers in Swaziland $(N=172)$ and their extension officers $(N=17)$. Quantitative data were collected through face-to-face interviews using a valid and reliable structured questionnaire. Descriptive statistics and one way analysis of variance (ANOVA) were applied to analyse the data. The results revealed that sugarcane farmers and extension officers perceive the Swaziland sugar industry to be ready for the introduction and subsequent use of ICTs to access sugarcane production information. The sugar industry infrastructure and other facilities that are necessary for the use of cell phones were perceived to be ready. All respondents possessed cell phones which they personally owned. The entire sugar industry had access to cellular network and electricity. It was also shown that some demographic variables of respondents did have an influence on their perceptions regarding the industry's readiness towards the use of cell phones to access information. The results of this study can provide guidance to the government and the sugar industry of Swaziland when considering implementing improved information dissemination based programmes.
\end{abstract}

Keywords: Cell phone, Extension, ICT, Sugarcane, Swaziland

\section{INTRODUCTION}

In a rapidly changing world, agricultural extension has been recognised as an essential mechanism for delivering knowledge, information and advice to a large majority of farmers (Richardson, 2003). Arkhi, Darvishi and Adibnejad (2008) noted that agricultural extension has an important role of connecting farmers and the research centres. The application of Information and Communication Technology (ICT) in the field of agriculture has been reported from different parts of the globe. ICTs have an important role of assisting extension in transferring up to date information to farmers as well as reporting the needs of farmers to research centres. According to Arkhi et al (2008), this process reduces the costs of travelling by removing the physical distances that could have been travelled by extension personnel in trying to reach and assist rural farmers.

Agriculture is one of the most important sectors in Swaziland and sugarcane is one of the major cash crops grown in the country. The sugar industry sector is the backbone of the Swazi

\footnotetext{
${ }^{1}$ Lecturer, Department of Agricultural Education and Extension, University of Swaziland, Luyengo, Swaziland, Email: mzmdlamini@gmail.com

${ }^{2}$ Associate Professor, Department of Agricultural Extension and Rural Resource Management, University of KwaZulu-Natal, Durban, South Africa, Email: worths@ukzn.ac.za
} 
economy according to the National Adaptation Strategy of Swaziland. It contributes approximately $18 \%$ towards the Gross Domestic Product (GDP), 35\% towards private sector wage employment, and $11 \%$ to national wage employment. Sugarcane production in Swaziland takes place in the lowveld part of the country due to its good soils and the favourable climatic conditions. The crop is grown under irrigation over a period of 11 to 12 months with annual harvests. This sector could benefit tremendously with the application of ICTs, especially in bringing changes to the livelihoods of the poor in the rural areas of Swaziland.

One of the most popular ICT applications is e-learning. With e-learning, available technologies can be used to enhance learning and expand access to information and knowledge within the agricultural sector of Swaziland. The use of e-learning in the field of agricultural extension is becoming popular in many countries due to the development of ICT. Omotayo (2005) observed that frontline extension workers who become the direct link between farmers and other actors in the extension of agricultural knowledge and information systems are well positioned to make use of ICT to access expert knowledge or other types of information that could improve a farmer's ability to improve productivity.

ICT programme implementation in a developing country relies on various facets such as infrastructure, government policy, cultural factors, organisational factors, and human resources. Human resources are one of the crucial factors to help diffuse the ICT programme. Hence, this article focuses mainly on the human resource factors to investigate the readiness of the Swaziland sugar industry towards the use of ICTs (specifically cell phones) to access sugarcane production information. Assuming that these factors can be clearly identified, the information can be used by the sugar industry to increase the use of this approach of learning to improve sugarcane productivity among smallholder sugarcane growers in Swaziland. This will in turn have a positive impact on sustainable agricultural development and the economy of the country. The results will also serve as a valuable baseline of ICT diffusion within the sugar industry of Swaziland so that the growth or decline of this approach could be tracked.

Therefore, the main purpose of this article was to investigate the readiness of the Swaziland sugar industry, as perceived by smallholder sugarcane farmers and their extension officers, on the use of ICTs to access sugarcane production information. The study was performed with the guidance of the following research objectives:

1. Describe respondents by demographic variables.

2. Determine the perceived readiness level of the Swaziland sugar industry towards the use of ICT to access sugarcane production information.

3. Determine the availability and usage of ICT hardware within the sugar industry of Swaziland.

4. Determine if demographic variables of respondents (age, gender, education, experience, marital status, and respondent's category) affect their perception of the sugar industry's readiness towards the use of ICTs to access sugarcane production information.

\section{LITERATURE REVIEW}

The use of ICT is becoming more widespread in different sectors including agriculture. One of the most popular ICT applications is e-learning whereby available technologies are used to enhance learning and facilitate information access in the agricultural sector. The readiness of farmers and extension workers to use ICT in any community is an issue that needs to be addressed before that technology is introduced (Kauffman \& Kumar, 2005). The assessment of 
ICT readiness allows for proper planning for its integration so that efforts are focused in areas where further attention is required (Krull, 2003).

Readiness is defined by So and Swatman (2006) as being mentally or physically prepared for some activity or action. Trinidad (2002) emphasised that it is crucial to conduct an initial assessment of preparedness for e-learning amongst farmers and extension workers before a new technology is introduced. Trinidad (2002) further explains that this assessment should consist of several technological factors such as computer, internet and telephone line readiness. Another factor to consider is that of education which includes network learning, network society, network economy, network policy, English proficiency, and computer literacy. Watkins (2003) proposed that the assessment for e-learning readiness should include technology access, technology skills, online reading and internet chat. Some studies have also indicated that demographic and background characteristics such as age, gender, ethnicity, marital status, level of education, as well as experience with computers and the internet have an influence on ICT adoption, thus they also need to be assessed (Durndell \& Thomson, 1997; Muilenberge \& Berge, 2005; Ong \& Lai, 2006; Teo \& Lim, 2000; Whitley Jr, 1997)

According to Darab and Montazer (2011), infrastructure readiness assessment focuses on evaluating whether the existing infrastructure could sustain the new intervention and if not, such infrastructure needs to be provided. Human resource readiness, however, focuses on evaluating the incumbents in terms of motivation, attitude resistance, and skills required in providing e-learning. Machado (2007) recommended that prior to the implementation of elearning services, it is important to understand the administrator's vision and their abilities in implementing policies and strategies that support e-learning. It was further highlighted that these policies and strategies help in capacitating other stakeholders in terms of motivation and training.

\section{METHODOLOGY}

The study was conducted in 2015 within the lowveld region of Swaziland where sugarcane is mainly grown. The survey method using the interview technique was used in the study. This study also carried quantitative research to investigate the perceptions of sugarcane farmers and extension officers' readiness towards the use of ICT to access sugarcane production information. Four enumerators who had recently graduated from the University of Swaziland were engaged and trained on how to collect the data. The study was a census and a structured questionnaire was used to interview all the smallholder sugarcane farmers $(\mathrm{N}=172)$ who were actively growing sugarcane in Swaziland, as well as all the sugarcane extension officers $(\mathrm{N}=17)$ during the year of data collection.

A total of 201 questionnaires were issued to respondents and 189 (172 famers and 17 extension officers) were valid, providing an effective response rate of $94 \%$. Data were collected with a pre-tested schedule. Descriptive statistics and one way analysis of variance (ANOVA) were applied to analyse the data using the statistical software programme, Statistical Package for the Social Sciences (SPSS) version 20. The study aimed at determining any significant difference in the readiness perceptions of respondents due to background and demographic variables. A series of ANOVAs were performed to observe if the overall responses of the participants differ according to age, gender, education level, experience, marital status, and respondents' category. For testing significant differences, the alpha level was set at $95 \%(P<.05)$. Frame, 
selection and non-response errors were controlled in accordance with suggestions by Miller and Smith (1983).

An up to date list of all the active sugarcane growers was obtained from the Swaziland Sugar Association (SSA) extension services, thus controlling frame error. In order to control selection error, the list was purged for duplication of names and for those growers who were no longer in the business of growing sugarcane. A panel of experts consisting of two senior extension managers from SSA, one extension manager from The Food and Agricultural Organisation (Swaziland), and four academic staff members from the University of Swaziland (Department of Agricultural Education and Extension) were asked to review the instrument for content validity. Experts attested to the content validity of the instrument. A pilot test was conducted to determine the reliability of the questionnaire using cane growers from Vuvulane Estate who did not participate in the final study. Kuder Richardson (KR21) and Cronbach alpha procedures were used to calculate reliability coefficients of independent variables.

\subsection{Data collection instrument}

The questionnaire was divided into three parts: Part I listed items related to demographic variables and background information. Respondents were asked to circle their choices or fill information in the space provided. Part II contained items that would enable the implementation and subsequent use of ICT to access information within the sugar industry of Swaziland. Respondents were asked to fill the information in the space provided or circle their choices against each item. Part III consisted of items pertaining to the readiness of respondents towards the use of ICT to access sugarcane production information. Respondents were asked to rate each item of readiness using a Likert type scale ranging from one (strongly disagree) to six (strongly agree). A cut-off point of 3.5 was established such that all those responses with a mean value of less than or equal to 3.5 were categorised as having disagreed and all those above 3.5 were recorded as agreed.

\section{THEORETICAL FRAMEWORK FOR THE STUDY}

Extension exists to make agricultural information accessible to farmers and other stakeholders who need it to improve productivity (Salau, Saingbe \& Garba, 2013). However, according to Salau et al (2013), extension is currently struggling to meet this goal. The public extension service, especially in the sub-Saharan Africa region, has not been effective enough in conveying agricultural information to farmers. Farmers sometimes resist a much-needed improved technique, not because they do not want it, but because they are ignorant of the practice (Salau et al, 2013).

Masuki et al (2010) argue that agricultural information plays an important role in the development of smallholder farmers towards increased production. They noted that most smallholder farmers are located in the rural areas, therefore an increase in their production automatically leads to more desirable lifestyles for the rural people, food security, and national economies of the countries where they operate. When reliable and accurate information is availed on time to smallholder farmers, they can reduce their production costs, improve their productivity, and have collective bargaining with buyers and input suppliers, thus, maximising their profit margins (Ikoja-Odongo \& Ocholla, 2004; Masuki et al, 2010; Richardson, 2003).

A conceptual framework was developed to demonstrate the differences between smallholder farmers and large-scale famers with regards to accessing information via ICT, highlighting the 
influence of barriers, information management, and readiness for ICT introduction. In this context of farmers, extension and ICTs, readiness addresses four elements, namely the readiness of farmers to adopt/use ICTs to access information, the readiness of extension officers to adopt/use ICTs to access and disseminate information, provision of ICT infrastructure, and the ability to manage the communications infrastructure.

As shown in Figure 1, the readiness of smallholder rural farmers towards the use of ICT to access information is perceived to be very low. This has the potential to create poor uptake and usage of ICT for information access, thus leaving smallholder farmers vulnerable to poor decision-making about the production and other operations of their farming enterprises which then leads to lower than possible yields. Conversely, Figure 1 also shows how prepared largerscale farmers are for the introduction of ICT to access crucial information for improving their productivity.

This framework allows for separating out the causes of readiness or lack thereof to use ICTs in relation to information access and dissemination. This will facilitate policy and practical decisions in relation to making sure that any issues related to farmers and/or extension officers not being ready to use ICTs are accurately targeted. Similarly, issues related to the provision and management of ICT infrastructure can be clearly identified (and separated from other issues) and addressed accordingly.

\section{RESULTS AND DISCUSSION}

The data discussed in this paper were analysed using the framework in Figure 1. Respondents were asked to rate how they perceive each of the readiness domains (farmers, extension officers, infrastructure, and management) to be ready for the introduction of ICT to enhance information access. 


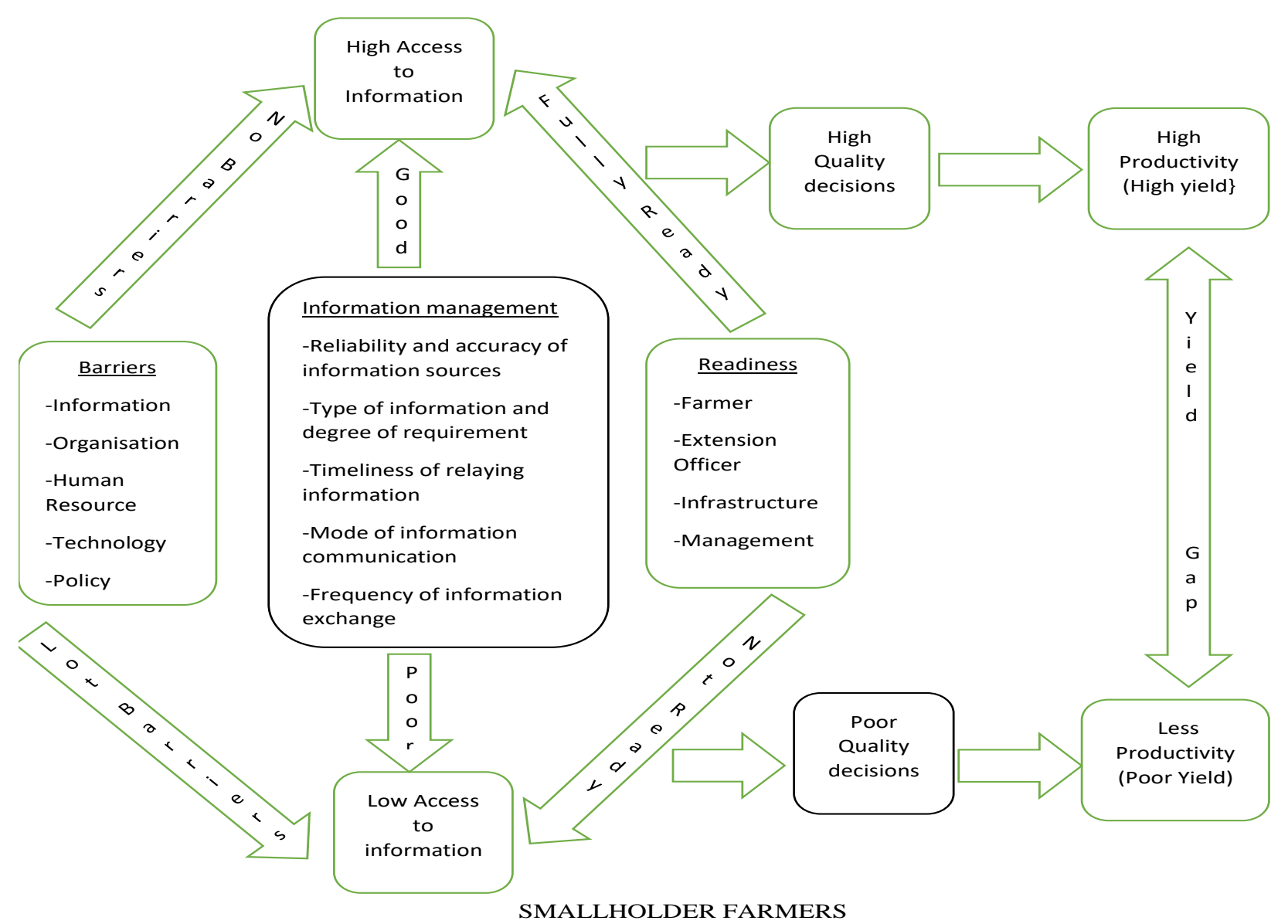

Figure 1: Diagrammatic representation of how information access influences the productivity gap between smallholder and large-scale farmers

The reporting of results and discussions have been organised into four sections. The first section describes demographic variables of respondents. The second section reports the perceived readiness level of respondents towards the use of ICT in accessing sugarcane production information. The items were arranged into four domains of farmer readiness, extension officer readiness, infrastructure readiness, and extension management readiness. The third section reports the availability and usage of ICT hardware within the sugar industry of Swaziland, while the fourth section describes if demographic variables of respondents did affect their perception of the industry's readiness towards the use of ICTs in accessing sugarcane production information.

\subsection{Respondents' demographic variables}

Respondents were described according to their demographic variables including age, gender, education level, sugarcane production experience, and marital status. Results are presented in Table 1 and they reflect that the majority of the respondents are in the age group of 30-39 years (38.6\%), followed by $40-49$ years (19\%) for both farmers and extension officers. With regards to gender, both farmers and extension officers had higher proportions of male respondents $(74.6 \%)$. 
Table 1: Respondents' demographic profile

\begin{tabular}{|l|l|l|l|l|l|l|l|}
\hline \multicolumn{2}{c}{} & \multicolumn{2}{c}{ Farmer $\mathbf{( N = 1 7 2 )}$} & \multicolumn{2}{c|}{ EOs (N=17) } & \multicolumn{2}{c|}{ Total (N=189) } \\
\hline Characteristic & Category & $\mathbf{F}$ & $\mathbf{\%}$ & $\mathbf{F}$ & $\mathbf{\%}$ & $\mathbf{F}$ & \% \\
\hline \multirow{4}{*}{ Age } & $19-29$ & 24 & 13.9 & 3 & 17.6 & 27 & 14.3 \\
\cline { 2 - 8 } & $30-39$ & 64 & 37.2 & 9 & 53.0 & 73 & 38.6 \\
\cline { 2 - 8 } & $40-49$ & 32 & 18.6 & 4 & 23.5 & 36 & 19.0 \\
\cline { 2 - 8 } & $50-59$ & 25 & 14.5 & 1 & 5.9 & 26 & 13.8 \\
\cline { 2 - 8 } & $>60$ & 27 & 15.8 & 0 & 0 & 27 & 14.3 \\
\hline \multirow{4}{*}{ Gender } & Males & 124 & 72.1 & 17 & 100 & 141 & 74.6 \\
\cline { 2 - 8 } & Females & 48 & 27.9 & 0 & 0 & 48 & 25.4 \\
\hline \multirow{5}{*}{ Education } & None & 8 & 4.7 & 0 & 0 & 8 & 4.2 \\
\cline { 2 - 8 } & Primary & 30 & 17.4 & 0 & 0 & 30 & 15.9 \\
\cline { 2 - 8 } & Secondary & 38 & 22.1 & 0 & 0 & 38 & 20.1 \\
\cline { 2 - 8 } & High school & 56 & 32.6 & 0 & 0 & 56 & 29.6 \\
\cline { 2 - 8 } & Tertiary & 40 & 23.3 & 17 & 100 & 57 & 30.2 \\
\hline & $1-5$ & 69 & 40.1 & 4 & 23.5 & 73 & 38.6 \\
\cline { 2 - 8 } & $6-10$ & 28 & 16.3 & 7 & 41.2 & 35 & 18.5 \\
\cline { 2 - 8 } & $11-15$ & 40 & 23.3 & 3 & 17.6 & 43 & 22.8 \\
\cline { 2 - 8 } & $16-20$ & 14 & 8.1 & 2 & 11.8 & 16 & 8.5 \\
\cline { 2 - 8 } & $21<$ & 21 & 12.2 & 1 & 5.9 & 22 & 11.6 \\
\hline \multirow{5}{*}{ Marital Status } & Married & 151 & 87.8 & 13 & 76.5 & 164 & 86.8 \\
\cline { 2 - 8 } & Single & 21 & 12.2 & 4 & 23.5 & 25 & 13.2 \\
\hline
\end{tabular}

From the results, it is evident that the sugar industry of Swaziland is still male dominated when it comes to leadership of the smallholder farmer groups. Worth noting again is that all $(100 \%)$ the sugarcane extension officers were male. This observation opens the need to encourage women to tap into this industry. The educational status of the farmer respondents shows that the majority $(30 \%)$ had gone up to tertiary education followed by those who went as far as high school (29.6\%) and the rest never finished secondary school.

Regarding the extension officers, all had gone through tertiary education and this is mainly due to the minimum requirement set by SSA for one to be employed as an extension officer. With regards to the number of years of service, both farmers and extension officers had the majority of respondents (38.6\%) with 1-5 years of service in the sugar industry. These were followed by those respondents who had 11-15 years of experience (22.8\%). Very few had more than 21 years of experience. The marital status of respondents indicates that the majority $(86.8 \%)$ were married. Therefore, it could be concluded that most of the study respondents were middle aged, married males, educated, with 1-5 years of sugarcane production experience. An educated individual in the Swazi context refers to someone who has completed high school education and a middle aged person is one falling between 30 and 39 years of age.

\subsection{Readiness level of the sugar industry}

Research objective two sought to determine the perceived readiness level of the Swaziland sugar industry towards the use of ICT in accessing sugarcane production information. The results are presented in Table 2. 


\subsubsection{Farmer readiness}

The results indicate an overall mean score of $\mathrm{M}=4.37(\mathrm{SD}=.95)$ on famers' readiness towards the use of ICT for information access within the sugar industry. This mean score implies that farmers are perceived by the majority of respondents to be ready for the use of ICT, specifically cell phones, as a technology for disseminating information within the sugar industry of Swaziland. This is also supported by the fact that the majority of the sugarcane farmers possessed cell phones which they personally owned and were already using these devices to disseminate work-related information within and outside their workstations. It was also highlighted that most of these farmers were using their own airtime to communicate workrelated issues during and after working hours.

\subsubsection{Extension officer readiness}

The overall perception of extension officer readiness towards the use of ICT has a mean score of $\mathrm{M}=5.12(\mathrm{SD}=.84)$ as indicated in Table 2. This mean score indicates that all respondents perceive extension officers to be ready for the implementation of cell phones as a technology for disseminating information within the sugarcane industry stakeholders. All extension officers interviewed possessed personal smart phones and all had gone through tertiary education which makes them ready for the introduction of such a technology. All respondents agreed that extension officers, with their high ICT competency, can improve their teaching and learning by integrating such technology in their extension programmes. Respondents also agreed that this is the right time for promoting the dissemination of information within the sugar industry of Swaziland.

\subsubsection{Infrastructure readiness}

Results shown in Table 2 indicates a mean score of $\mathrm{M}=5.05(\mathrm{SD}=.54)$ on infrastructure readiness for the use of ICT within the sugar industry. This is an indication that most respondents agreed that the infrastructure in the sugar industry of Swaziland is perceived to be ready for the use of cell phones as a technology for information dissemination. Respondents reported that they all have access to the cell phone network in their respective areas where sugarcane is grown. Network coverage is crucial for cell phone connectivity. Electricity, which supplies energy to the satellites and recharges cell phones, was reported to be accessible by all the respondents in their respective areas of sugarcane production. The availability of cell phone service centres within the vicinity of each mill makes it easy for the respondents to get immediate help when their cell phones have a problem. Airtime is also readily available in almost all the small grocery shops situated within the farmers' residential areas.

Table 2: Perception of readiness towards the use of ICT to access sugarcane production information

\begin{tabular}{|l|c|c|c|c|c|c|c|}
\hline Items & \multicolumn{2}{|c|}{$\begin{array}{c}\text { Farmers } \\
(\mathbf{N = 1 7 2})\end{array}$} & \multicolumn{2}{c|}{$\begin{array}{c}\text { EOs } \\
(\mathbf{N = 1 7 )}\end{array}$} & \multicolumn{2}{c|}{$\begin{array}{c}\text { Total } \\
(\mathbf{N = 1 8 9})\end{array}$} & \\
\hline Farmer Readiness & M & SD & M & SD & M & SD & CA \\
\hline Farmers know that ICTs can be used & 4.60 & 1.20 & 4.53 & .94 & 4.59 & 1.18 & \\
\hline Farmers are capable of using ICTs & 4.66 & 1.04 & 4.06 & .97 & 4.61 & 1.04 & \\
\hline Farmers have the skill to use ICTs & 4.18 & 1.29 & 3.18 & 1.24 & 4.09 & 1.32 & \\
\hline Farmers are ready to use ICTs & 4.48 & 1.24 & 3.76 & 1.20 & 4.41 & 1.26 & \\
\hline
\end{tabular}


Vol. 47 No. 3, 2019: $92-107$

http://dx.doi.org/10.17159/2413-3221/2019/v47n3a518

(License: CC BY 4.0)

\begin{tabular}{|c|c|c|c|c|c|c|c|}
\hline Internet access is not a farmer's problem & 4.18 & 1.44 & 3.53 & 1.74 & 4.12 & 1.48 & \\
\hline Overall & 4.42 & .94 & 3.81 & .89 & 4.37 & .95 & .81 \\
\hline \multicolumn{8}{|l|}{ Extension Officer Readiness } \\
\hline E0s know how to use ICTs & 4.99 & .79 & 5.47 & .51 & 5.04 & .79 & \\
\hline ICTs can improve extension & 5.10 & .56 & 5.35 & .49 & 5.13 & .56 & \\
\hline Now is the time to promote ICT usage & 5.18 & .48 & 5.41 & .51 & 5.20 & .49 & \\
\hline $\begin{array}{l}\text { E0s are ready to integrate ICT in their } \\
\text { extension programmes }\end{array}$ & 5.10 & .63 & 5.18 & .73 & 5.11 & .64 & \\
\hline E0s have enough ICT competency & 5.13 & .47 & 5.06 & 1.09 & 5.13 & .55 & \\
\hline Overall & 5.10 & .47 & 5.29 & .45 & 5.12 & .47 & .82 \\
\hline \multicolumn{8}{|l|}{ Infrastructure Readiness } \\
\hline $\begin{array}{l}\text { Infrastructure supports ICT } \\
\text { implementation }\end{array}$ & 5.02 & .78 & 4.41 & .87 & 4.96 & .81 & \\
\hline Adequate ICT support from industry & 5.10 & .64 & 4.71 & 1.21 & 5.07 & .72 & \\
\hline $\begin{array}{l}\text { Industry has enough budget to support } \\
\text { ICT usage }\end{array}$ & 5.14 & .52 & 4.94 & .97 & 5.12 & .58 & \\
\hline Overall & 5.09 & .50 & 4.69 & .76 & 5.05 & .54 & .75 \\
\hline \multicolumn{8}{|l|}{ Management Readiness } \\
\hline Extension management knows ICT & 5.25 & .58 & 5.53 & .72 & 5.28 & .60 & \\
\hline Extension management supports ICT & 5.19 & .65 & 5.06 & .75 & 5.17 & .66 & \\
\hline $\begin{array}{l}\text { Management has a plan for ICT } \\
\text { implementation }\end{array}$ & 5.25 & .58 & 5.53 & .72 & 5.28 & .60 & \\
\hline Overall & 5.22 & .59 & 5.29 & .69 & 5.22 & .60 & .90 \\
\hline
\end{tabular}

\subsubsection{Management readiness}

Management is perceived by most respondents to be ready for the use of ICT to circulate information within the sugar industry of Swaziland. This is indicated by the overall mean score of $M=5.22$ (0.60) in Table 2. Respondents agreed that extension management know how to use ICTs, specifically cell phones, and the use of such technology was supported. They went on to confirm that a plan for the implementation of ICT usage was in the pipeline.

\subsection{Hardware availability and usage}

Any organisation that aims at adopting the use of ICT to access information must have at least the minimum hardware requirements and software to use that device. ICT hardware includes the physical equipment that will enable the sugar industry stakeholders to communicate effectively. Without appropriate equipment and easy access, it is difficult to access information via ICT (Oliver \& Towers, 2000). Broadbent (2001) however stated that this does not require a large infrastructure. A well working internet connectivity and enough supply of communication devices would be sufficient for an effective communication system.

Objective three of the study therefore enquired from both farmers and extension officers about the hardware availability and usage within the sugar industry. In particular, the focus was on the cell phone technology, the internet, and other factors associated with mobile cellular usage. The results are presented in Table 3. These factors included cell phone possession, cell phone ownership, cell phone brand, social media, transport, mobile network coverage, electricity availability, distance from the mill, and type of cell phone used. 
Table 3: Network and cell phone accessories

\begin{tabular}{|c|c|c|c|c|c|c|c|}
\hline \multirow{2}{*}{ Variable } & \multirow[b]{2}{*}{ Category } & \multicolumn{2}{|c|}{$\begin{array}{l}\text { Farmer } \\
(\mathrm{N}=172)\end{array}$} & \multicolumn{2}{|c|}{ EOs $(\mathbf{N}=17)$} & \multicolumn{2}{|c|}{ Total $(\mathrm{N}=189)$} \\
\hline & & $\mathbf{F}$ & $\%$ & $\mathbf{F}$ & $\%$ & $\mathbf{F}$ & $\%$ \\
\hline \multirow{2}{*}{ Possession } & Yes & 172 & 100 & 17 & 100 & 189 & 100 \\
\hline & No & 0 & 0 & 0 & 0 & 0 & 0 \\
\hline \multirow{2}{*}{ Ownership } & Personal & 166 & 96.5 & 17 & 100 & 183 & 96.8 \\
\hline & Company & 6 & 3.5 & 0 & 0 & 6 & 3.2 \\
\hline \multirow{5}{*}{ Brand } & Nokia & 125 & 72.5 & 9 & 52.9 & 134 & 70.9 \\
\hline & Samsung & 21 & 12.3 & 5 & 29.4 & 26 & 13.8 \\
\hline & Huawei & 8 & 4.7 & 1 & 5.9 & 9 & 4.8 \\
\hline & ZTE & 6 & 3.5 & 0 & 0 & 6 & 3.2 \\
\hline & Other & 12 & 7 & 2 & 11.8 & 14 & 7.4 \\
\hline \multirow{2}{*}{ Type } & Regular phone & 108 & 62.8 & 4 & 23.5 & 112 & 59.3 \\
\hline & Smartphone & 64 & 37.2 & 13 & 76.5 & 77 & 40.7 \\
\hline \multirow{2}{*}{ Social media } & Yes & 99 & 57.6 & 14 & 82.4 & 113 & 59.7 \\
\hline & No & 73 & 42.4 & 3 & 17.6 & 76 & 40.2 \\
\hline \multirow{2}{*}{ Network } & Available & 172 & 100 & 17 & 100 & 189 & 100 \\
\hline & Not available & 0 & 0 & 0 & 0 & 0 & 0 \\
\hline \multirow{2}{*}{ Electricity } & Available & 172 & 100 & 17 & 100 & 189 & 100 \\
\hline & Not available & 0 & 0 & 0 & 0 & 0 & 0 \\
\hline \multirow{4}{*}{ Transport } & Foot & 111 & 64.5 & 0 & 0 & 111 & 58.7 \\
\hline & Bicycle & 15 & 8.7 & 0 & 0 & 15 & 7.9 \\
\hline & Motorbike & 6 & 3.5 & 0 & 0 & 6 & 3.2 \\
\hline & Vehicle & 40 & 23.3 & 17 & 100 & 57 & 30.2 \\
\hline \multirow{4}{*}{ Mill distance } & $6-19$ & 12 & 7 & 1 & 5.9 & 13 & 6.9 \\
\hline & $20-39$ & 137 & 79.6 & 11 & 64.7 & 148 & 78.3 \\
\hline & $40-59$ & 11 & 6.4 & 4 & 23.5 & 15 & 7.9 \\
\hline & $60<$ & 12 & 7 & 1 & 5.9 & 13 & 6.9 \\
\hline
\end{tabular}

\subsubsection{Cell phone possession and ownership}

Table 3 indicates that all farmers and extension officers (100\%) in the sugar industry possessed cell phones and these cell phone devices are used in disseminating work-related information amongst the Swaziland sugar industry stakeholders on a daily basis. With regards to ownership of these gadgets, the study revealed that the large majority of the respondents $(98.6 \%)$ personally owned the cell phones, while only $3.2 \%$ reported that they were using company owned devices. All the respondents reported that they use their own airtime to disseminate work-related information using their cell phones. This is an indication that smallholder sugarcane farmers and their extension officers have realised the importance of using cell phone technology in the dissemination of information timely and accurately amongst themselves and other sugarcane stakeholders. 


\subsubsection{Cell phone type and brand}

The majority of the respondents reported that they were using the Nokia brand $(70.9 \%)$ of cell phones, followed by the Samsung brand (13.8\%) as shown in Table 3. This could be attributed to the fact that these brands are readily available in the market, affordable and easy to fix. With regards to the type of cell phone being used by the respondents, most reported that they were using the regular type $(59.3 \%)$ of phone mainly because they were cheaper and less complicated to use. Only $40.7 \%$ of the respondents reported that they were using smart phones. Regular phones are cheaper and easy to operate, whereas smart phones are expensive and require a certain level of skill to operate them.

\subsubsection{Network and electricity}

As illustrated in Table 3, all smallholder sugarcane farmers and their extension officers reported that they have access to cellular networks almost everywhere within the sugar industry of Swaziland. The only difference reported was the strength of the cellular network as some places had weaker connections than others. Topography and satellite distribution does influence the network strength of a given area. Regarding electricity, all respondents reported that they had access to electricity in their homes and that is where they recharge their cell phones. This is mainly due to the rural electrification project driven by the government of Swaziland which has seen a number of rural areas being provided with affordable electricity. The availability of electricity and mobile cellular network within the sugar industry of Swaziland has made the sugar industry ready for the implementation of most ICT programmes, especially the use of cellular phones.

\subsubsection{Transport and distance from the mill}

The study revealed that most respondents (58.7\%) travel by foot while carrying out their day to day sugarcane production activities. Only $41.3 \%$ use cars, motorbikes and bicycles. The use of cell phones to disseminate information helps in reducing the distance travelled by the farmers and their extension officers whenever they want to share information. The study also revealed that most respondents $(78.3 \%$ ) were within a radius of 20 to $39 \mathrm{~km}$ from the mill. Most input suppliers and service providers in the sugar industry are located next to the sugar mills. The use of cell phones helps both farmers and extension officers to acquire information accurately and timeously from such institutions, thus reducing the travelling costs. Such an arrangement also increases the time spent on supervising different daily activities in the farm, thereby improving productivity.

\subsubsection{Social media}

Grouping farmers in order to be able to share information to them as a group while they physically remain in their respective workstations is very important. This can best be achieved by the use of social media accessible via cell phones. The results revealed that more than half of the respondents (59.7\%) are not yet connected to any social media (Table 3). Only $40.3 \%$ are connected and this presents a need to educate and encourage the respondents to use social media for accessing new information on sugarcane production. 


\subsection{Influence of demographic variables of respondents on their responses}

The fourth research objective of the study aimed at determining any significant difference in the readiness perceptions of respondents due to background and demographic variables. A series of ANOVAs were performed to observe if the overall responses of the participants differ according to age, gender, education level, experience, marital status, and respondents' category. The results are presented in Table 4.

\subsubsection{Age}

The results in Table 4 indicate that age had an influence on respondents' perceptions towards farmer readiness $[\mathrm{F}(4,184)=2.83, \mathrm{P}=.027]$. The study demonstrated that the age range $60<$ years old is more positive in the perception of farmer readiness and this finding is in line with different studies which have examined the effect of age differences on technology adoption (Burton-Jones \& Hubona, 2003; Rezaei et al, 2008; Venkatesh et al, 2003).

\subsubsection{Gender}

The study revealed that gender had an influence on respondents' perception towards infrastructure readiness $[\mathrm{F}(1,187)=4.14, \mathrm{P}=.043]$. Many authors (Joiner et al, 2005; Muilenburg \& Berge, 2005; Ong \& Lai, 2006; Teo \& Lim, 2000; Young, 2000) have reported significant differences between genders in the adoption behaviour of ICTs, however, the unbalanced proportion of males to females ( $74 \%$ males and $26 \%$ females) could also not be ruled out as a cause for this difference.

\subsubsection{Experience}

Sugarcane production experience was found to have an influence on the perceptions of respondents towards two variables of readiness and these were farmer readiness $[\mathrm{F}(4,184)=$ 3.69, $\mathrm{P}=.006]$ and management readiness [F $(4,184=3.08, \mathrm{P}=.017]$. A strong positive perception of readiness amongst respondents with more experience was observed for both the farmer readiness variable and management readiness variable. 
Table 4: One-way ANOVA of readiness

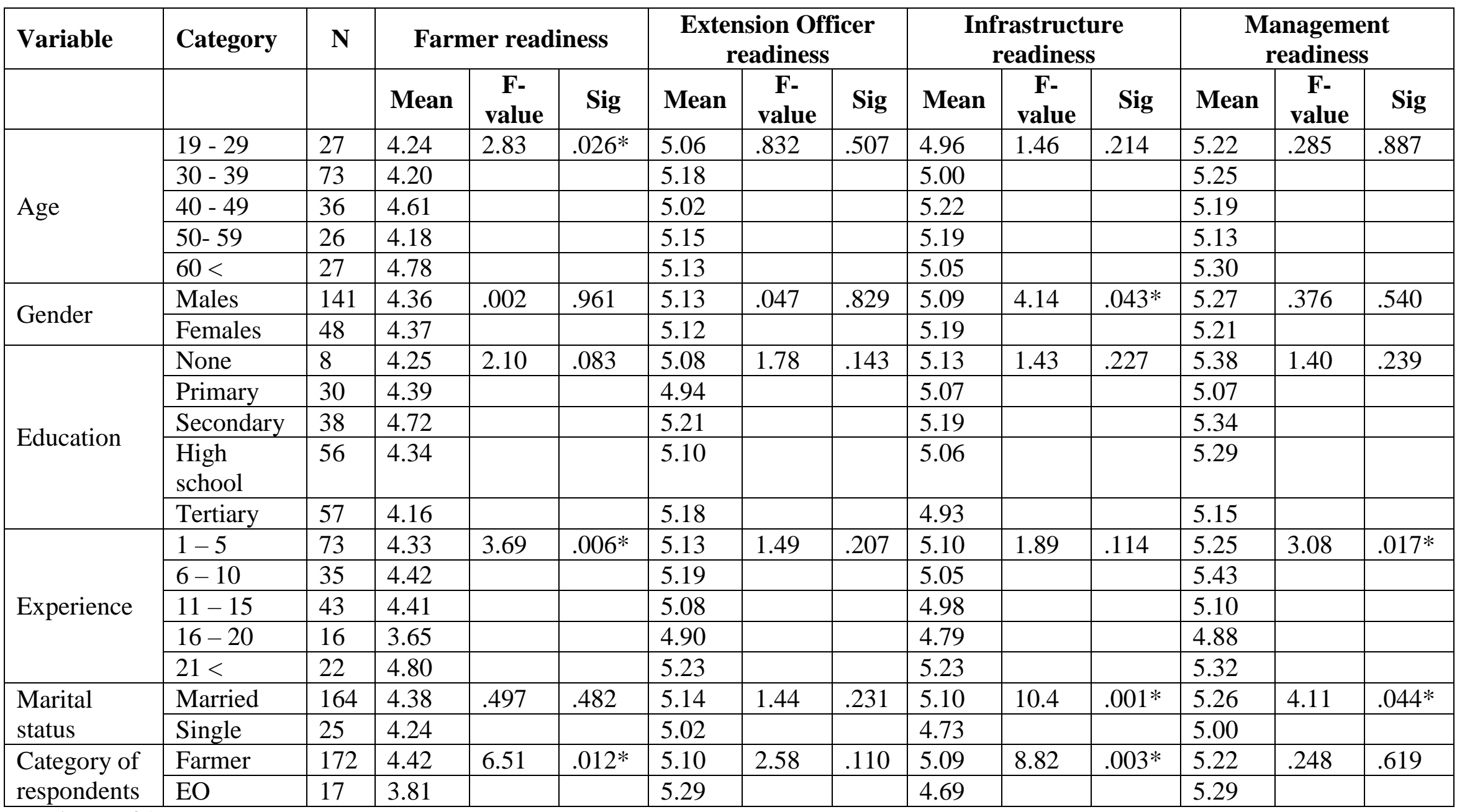

Note: $*=\mathrm{P}<.05$ 


\subsubsection{Category of respondents}

Table 4 indicates that this independent variable had an influence on respondents' perceptions towards two variables which are farmer readiness $[\mathrm{F}(1,187)=6.51, \mathrm{P}=.012]$ and infrastructure readiness $[\mathrm{F}(1,187)=8.82, \mathrm{P}=.003]$. Farmers viewed themselves more positively in terms of readiness whereas extension officers were less positive. With regards to infrastructure readiness, extension officers were more positive on its readiness. These differences could be attributed to the unbalanced proportion of extension officers to farmers (91\% farmers and 9\% extension officers).

Education level was the only independent variable which did not have any influence on the perceptions of respondents towards the sugar industry's readiness. This therefore implies that there is a need to consider those variables which have an influence on respondents' perceptions when considering implementing the use of ICT to access sugarcane production information in Swaziland. Extension officer readiness was the only dependent variable that was not influenced by any of the independent variables.

\section{CONCLUSION AND RECOMMENDATIONS}

Cell phones have a large potential to revolutionise the way information knowledge and new technology is managed, developed and delivered to farmers. Smallholder sugarcane farmers need assistance from intermediaries to adopt knowledge and information. In that regard, extension officers are suggested to be the effective intermediaries for delivering information and knowledge to sugarcane farmers. Therefore, assessment of readiness of both farmers and extension officers towards the use of cell phones as communication technology is crucial.

The findings of the research have shown that all four factors of readiness have been perceived as ready for the implementation of cell phone technology. These readiness factors include farmer readiness, extension officer readiness, infrastructure readiness, and management readiness. These findings inform the sugar industry and the government of Swaziland that they can embark on implementing cell phone technology as a means of disseminating information within the sugar industry. The implementation of such a technology can cut down the costs of travelling and maximise time spent on other production issues within the farm, thus improving productivity. Accurate and timely information will be disseminated within the shortest time possible, thus improving the knowledge capacity of the smallholder farmers and also improving their decision making abilities.

With regards to the basic required mobile communication facilities within the Swaziland sugar industry, the study demonstrated a high readiness level as perceived by the respondents. All farmers and extension officers possessed personally owned cell phones which they use to disseminate information during and outside working hours. They also reported to have access to both network and electricity in almost all their respective areas where they grow their sugarcane. The availability of cellular network and electricity is necessary for the implementation of the cell phone technology for information dissemination. However, most farmers are using the regular type of phone which has fewer functions compared to the smart phone. This may restrict the farmers from accessing information on the internet or in a form of videos or pictures. There is therefore a need to train these farmers to upgrade themselves to smart phones so that they may obtain more information via their cell phones. Furthermore, most of the farmers travel by foot when conducting their daily activities and this has a negative 
impact when it comes to gathering or disseminating information timely. The use of cell phone technology as a communication device can mitigate this challenge.

Based on these findings, the sugar industry of Swaziland can effectively use the presented scenario of mobile cellular technology to improve information access amongst its sugarcane production stakeholders, especially smallholder farmers. This could be through ensuring that every smallholder sugarcane farmer is provided with a smart phone, taught how to use it, and could be provided with minimum airtime on a monthly basis. The overall cost of these could be deducted from the proceeds of their harvest as is the case with other production inputs. Another opportunity that exists is that of negotiating for a group treatment of the sugarcane farmers from the mobile service provider where benefits of special rates and the ability to send group information to farmers could be discussed.

\section{REFERENCES}

ARKHI, S., DARVISHI, E. \& ADIBNEJAD, M., 2008. The role of ICT in agricultural extension and education and natural resources to attained sustainable development. Indian Res. J. Ext. Edu., 15(2):1.

BROADBENT, B., 2001. Tips to help decide if your organisation is ready for e-learning. Available from: http://icde.net/en/arshive/articles/012.htm

BURTON-JONES, A. \& HUBONA, G.S., 2003. The mediation of external variables in the technology acceptance model. Working Paper. Georgia State University, United States of America.

DARAB, B., \& MONTAZER, G.A., 2011. An eclectic model for assessing e-learning readiness in the Iranian universities. Comput. Educ., 56(3):900-910.

DURNDELL, A., \& THOMSON, K., 1997. Gender and computing: A decade of change. Comput. Educ., 28(1):1-9.

IKOJA-ODONGO, R. \& OCHOLLA, D.N., 2004. Information seeking behavior of the informal sector entrepreneurs: The Uganda experience. LIBRI., 54(1):54-66.

JOINER, R., GAVIN, J., DUFFIELD, J., BROSNAN, M., CROOK, C., DURNDELL, A., MARAS, P., MILLER, J., SCOTT, A.J. \& LOVATT, P., 2005. Gender, internet identification, and internet anxiety: Correlates of internet use. Cyberpsychol. Behav., 8(4):371-378.

KAUFFMAN, R.J. \& KUMAR, A., 2005. A critical assessment of the capabilities of five measures for ICT development. Available from: http://misrc.umn.edu/workingpapers/fullpapers/2005/0506_031805.pdf

KRULL, A., 2003. ICT infrastructure and e-readiness assessment report: Estonia. Working Paper 5/2003. PRAXIS Centre for Policy Studies, Estonia.

MACHADO, C., 2007. Developing an e-readiness model for higher education institutions: Results of a focus group study. Br. J. Educ. Technol., 38(1):72-82.

MASUKI, K., KAMUGISHA, R., MOWO, J., TANUI, J., TUKAHIRWA, J., MOGOI, J. \& ADERA, E., 2010. Role of mobile phones in improving communication and information delivery for agricultural development: Lessons from South Western Uganda. Paper presented to The Workshop at Makerere University. Wakiso, Uganda. 
MILLER, L.E. \& SMITH, K.L., 1983. Handling non response-issues. J. Ext., 22:45-50.

MUILENBERGE, L.Y. \& BERGE, Z.L., 2005. Student barriers to online learning: A factor analytic study. Distant Educ., 26(1):29-48.

OLIVER, R. \& TOWERS, S., 2000. Up time: Information communication technology: Literacy and access for tertiary students in Australia. Canberra: Department of Education, Training and Youth Affairs.

OMOTAYO, A.M., 2005. Information Communication Technology (ICT) and agricultural extension: Emergency issues in transferring agricultural technology in developing countries. In Agricultural extension in Nigeria. Ilorin: Agricultural Extension Society of Nigeria.

ONG, C.S. \& LAI, J.Y., 2006. Gender differences in perceptions and relationships among dominants of e-learning acceptance. Comput. Human Behav., 22(5):816-829.

REZAEI, M., MOHAMMADI, H.M., ASADI, A. \& KALANTARY, K., 2008. Predicting elearning application in agricultural higher education using technology acceptance model. Turk. Online J. Distance Educ., 9(1):85-95.

RICHARDSON, D., 2003. Agricultural extension transforming ICTs! Championing universal access. Available from: kambing.ui.ac.id/onnopurbo/library/library-ref-eng/ref-eng2/physical/rural-telephony/Richardson_overview.pdf

SALAU, E.S., SAINGBE, N.D. \& GARBA, M.N., 2013. Agricultural information needs of small holder farmers in central agricultural zone of Nasarawa State. J. Agric. Ext., 17(2):113-121.

SO, K.K.T. \& SWATMAN, P.M.C., 2006. E-learning readiness of Hong Kong teachers. Paper presented to The Hong Kong IT in Education Conference. Hong Kong.

TEO, T. \& LIM, V., 2000. Gender differences in internet usage and task preferences. Behav. Inf. Technol., 19(4):283-295.

TRINIDAD, A.C., 2002. An initial assessment of the Philippines' preparedness for e-learning. Philippines. J. Third World Stud., 17(2):3-5.

VENKATESH, V., MORRIS, M.G., DAVIS, G.B. \& DAVIS, F.D., 2003. User acceptance of information technology: Towards a unified view. MIS. Q., 27(3):425-478.

WATKINS, R., 2003. Readiness for online learning self-assessment. In The 2003 Pfeiffer annual: Training (pp.139-150). San Francisco: Jossey-Bass-Pfeiffer.

WHITLEY JR, B.E., 1997. Gender differences in computer related attitudes and behaviour: A meta-analysis. Comput. Human Behav., 13(1):1-22.

YOUNG, B.J., 2000. Gender differences in student attitudes towards computers. J. Res. Comput. Educ., 33(2):204-217. 
